\title{
HYBRID SOL-GEL COATINGS DOPED WITH CERIUM TO PROTECT MAGNESIUM ALLOYS FROM CORROSION
}

\author{
HIBRIDNI SOL-GEL-NANOSI, DOPIRANI S CERIJEM, ZA \\ KOROZIJSKO ZAŠČITO MAGNEZIJEVIH ZLITIN
}

\author{
Noé Verner Murillo-Gutiérrez, Florence Ansart, Jean-Pierre Bonino, \\ Marie-Jöelle Menu, Marie Gressier \\ Université de Toulouse UPS-INP-CNRS, Institut Carnot CIRIMAT, 118 Route de Narbonne, 31062 - Toulouse CEDEX 09, France \\ murillo@chimie.ups-tlse.fr
}

Prejem rokopisa - received: 2014-05-12; sprejem za objavo - accepted for publication: 2014-09-03

doi:10.17222/mit.2014.077

Hybrid coatings produced via the sol-gel route were deposited onto an Elektron 21 magnesium alloy. The sol consisted of tetraethyl-orthosilicate (TEOS) and 3-(trimethoxysilyl)propylmethacrylate (MAP) to which corrosion inhibitors were added. The influence of the cerium concentration on the anti-corrosion properties of the hybrid coating is presented. Furthermore, the morphology of the organic/inorganic coatings deposited on the magnesium alloy was determined with scanning electron microscopy (SEM). In parallel, the electrochemical behavior during the immersion in a $0.05 \mathrm{M} \mathrm{NaCl}$ corrosive solution was studied with electrochemical impedance spectroscopy (EIS). It was proven that the hybrid films exhibit a high impedance modulus during the first hours of the immersion and that an addition of cerium to the sol with a concentration of $0.01 \mathrm{M}$ considerably increases the durability of the film, delaying its degradation during the immersion. In addition, this project especially focusses on determining the critical concentration of the cerium salt at which the impedance modulus of the hybrid coating strongly decreases during the immersion.

Keywords: magnesium, coating, sol-gel, corrosion inhibitor, EIS

Hibridni nanosi, pripravljeni s sol-gel-postopkom, so bili naneseni na magnezijevo zlitino Elektron 21. Osnova je bila tetraetil-ortosilikat (TEOS) in 3-(trimetoksisilil)propilmetakrilat (MAP), ki so ji bili dodani inhibitorji korozije. Predstavljen je vpliv koncentracije cerija na protikorozijske lastnosti hibridnega nanosa. Poleg tega je bila določena morfologija organskih/ neorganskih nanosov na magnezijevo zlitino z vrstičnim elektronskim mikroskopom (SEM). Vzporedno je bilo preučevano elektrokemijsko vedenje med potopitvijo v korozijsko raztopino $0,05 \mathrm{M} \mathrm{NaCl}, \mathrm{z}$ uporabo elektrokemijske impedančne spektroskopije (EIS). Dokazano je bilo, da izkazujejo hibridni nanosi visok impedančni modul med prvimi urami namakanja in da dodatek cerija osnovi v koncentraciji 0,01 M močno poveča zdržljivost nanosa z zadržanjem njegove degradacije med namakanjem. Ta projekt je bil usmerjen v določanje kritične koncentracije cerijeve soli, pri kateri se impedančni modul hibridnega nanosa močno zmanjša med namakanjem.

Ključne besede: magnezij, nanos, sol-gel, inhibitor korozije, EIS

\section{INTRODUCTION}

With a density equivalent to $2 / 3$ of that of aluminium, magnesium and its alloys are interesting weight-saving materials for the automotive and aeronautics industries. However, compared to steel and aluminium alloys, magnesium alloys have a very low corrosion resistance. In order to prevent this problem, various surface treatments and coatings have been developed with different techniques over the last few years ${ }^{1,2}$. However, most of these processes make use of chromium (Cr VI) compounds, nowadays forbidden by international regulations since these are classified as carcinogen, mutagenic and reprotoxic compounds. The sol-gel route is an efficient method to produce "green" coatings and their anti-corrosion performances have been proven successful on steel and aluminium alloys. ${ }^{3-5}$ This project aims to evaluate the anti-corrosive properties of a hybrid coating obtained via the sol-gel route and deposited on a cast Elektron 21 magnesium alloy (El21) and, secondly, to identify its mechanisms.

\section{METHODOLOGY}

\subsection{Preparation of the materials and coatings}

Samples with the dimensions of $40 \mathrm{~mm} \times 20 \mathrm{~mm} \times$ $6 \mathrm{~mm}$ were obtained by making cuttings from a cast Elektron 21 (El21) alloy. The chemical composition of this alloy is shown in Table 1. The samples were first mechanically polished with abrasive papers with a grit of up to grade 4000 , then with alumina paste $(3 \mu \mathrm{m}$ and $1 \mu \mathrm{m})$ and finally they were rinsed with ethanol and dried under a flux of cold air.

Table 1: Chemical composition of the Elektron 21 cast alloy in mass fractions, $w / \%$

Tabela 1: Kemijska sestava livne zlitine Elektron $21 \mathrm{v}$ masnih deležih, $w / \%$

\begin{tabular}{|c|c|c|c|c|c|c|}
\hline Element & $\mathrm{Nd}$ & $\mathrm{Gd}$ & $\mathrm{Zr}$ & $\mathrm{Zn}$ & $\begin{array}{c}\text { Other rare } \\
\text { earths }\end{array}$ & $\mathrm{Mg}$ \\
\hline$w / \%$ & 3.1 & 1.7 & 1 & 0.5 & $<0.4$ & Balance \\
\hline
\end{tabular}

The sols were produced by mixing the starting precursors consisting of tetraethyl-orthosilicate (TEOS) and 
3-(trimethoxysilyl)propyl-methacrylate (MAP), deionized water and ethanol with a molar ratio of $11: 1: 60$ : 80 , under constant stirring and at room temperature. In order to adjust the $\mathrm{pH}$ of the sol to 4 , nitric acid $\left(\mathrm{HNO}_{3}\right)$ was drop-added to the mixture when required. The production of cerium-doped sols was performed by adding cerium nitrate $\left(\mathrm{Ce}\left(\mathrm{NO}_{3}\right)_{3} \cdot 6 \mathrm{H}_{2} \mathrm{O}\right)$ at four different concentrations: $(0.005,0.01,0.05$ and 0.1$) \mathrm{mol} \mathrm{L}^{-1}$. The addition of the cerium salt was carried out by previously dissolving this compound in the corresponding water volume of the formulation. After maturing for $24 \mathrm{~h}$, the sols were deposited on the magnesium El21 substrates using the dip-coating technique, at a controlled withdrawal speed of $200 \mathrm{~mm} \mathrm{~min}^{-1}$. They were then dried at $60{ }^{\circ} \mathrm{C}$ for $20 \mathrm{~min}$.

\subsection{Characterization techniques}

The microstructures of the El21 substrate and the sol-gel coatings were analyzed with scanning electron microscopy (SEM) using a JEOL JSM-6510LV microscope, at an operating voltage of $20 \mathrm{kV}$. Electrochemical tests of the open circuit potential $\left(E_{\text {ocp }}\right)$ and electrochemical impedance spectroscopy (EIS) were performed in $0.05 \mathrm{~mol} \mathrm{~L}^{-1}$ of a $\mathrm{NaCl}$ corrosive solution at room temperature, using a Bio-Logic SP-150 potentiostat. The
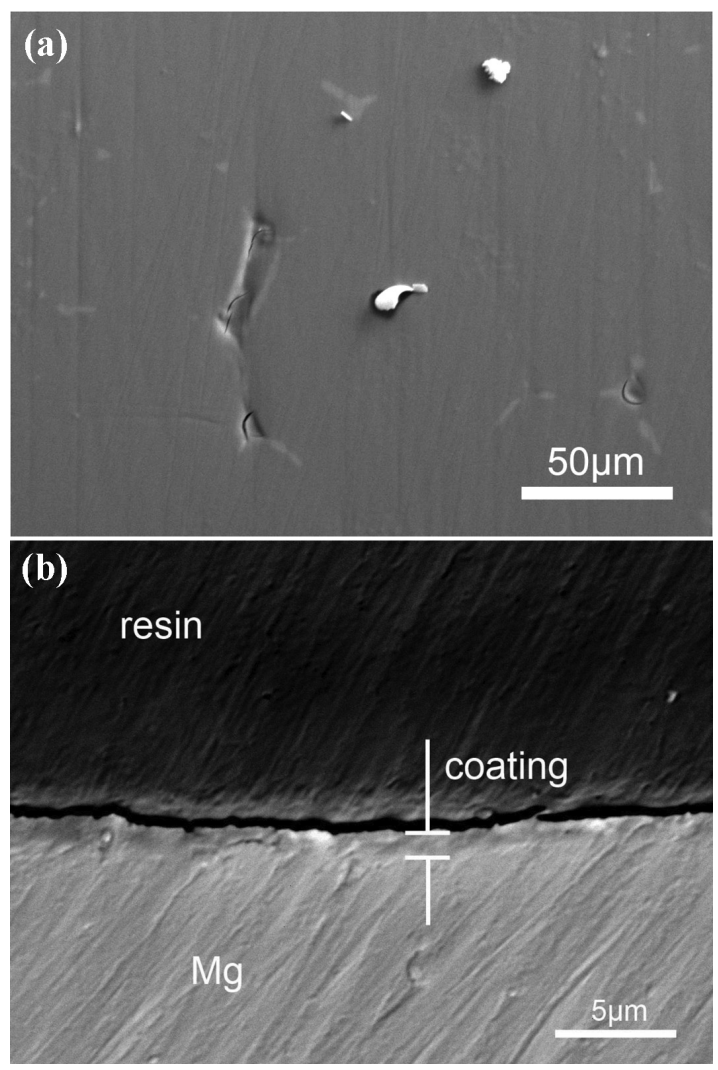

Figure 1: SEM images of the hybrid sol-gel coating on the El21 magnesium alloy: a) surface of the coating, b) cross-section of the substrate in the BSE mode

Slika 1: SEM-posnetka sol-gel hibridnega nanosa na magnezijevi zlitini E121: a) površina nanosa, b) prečni prerez podlage v BSE-načinu electrochemical cell consisted of a one-chamber threeelectrode cell, the working electrode having an exposed area of $2 \mathrm{~cm}^{2}$, delimited with an insulating tape. The reference and auxiliary electrodes included a saturated calomel electrode (SCE) and a platinum-foil electrode, respectively. The EIS spectra were drawn using the potentiostatic mode and a frequency ranging from 100 $\mathrm{mHz}$ and $10 \mathrm{mHz}$, with an applied voltage oscillation of $10 \mathrm{mV}$ vs. OCP. For each test, three samples were analyzed in order to check the reproducibility of the tests.

\section{RESULTS AND DISCUSSION}

\subsection{Morphology of the hybrid coatings}

The microstructure of a hybrid sol-gel coating was first observed with SEM (Figure 1). The surface of the coating (a) shows a homogeneous surface, with the presence of some cracks and defects spotted in the neodymium-rich zones. The origin of these defects may be attributed to the formation of a galvanic couple between this intermetallic phase and the alpha phase of magnesium $^{2}$, and to the internal stresses of the hybrid coating that lead to fracture. A cross-sectional observation of the substrate in the BSE (back-scattered electrons) mode (b) allows the thickness of the hybrid coating to be measured at around $1 \mu \mathrm{m}$.

\subsection{Electrochemical characteristics of the hybrid coat- ings}

Firstly, the open-circuit potential of the samples was recorded during the immersion of the substrates in a corrosive solution containing $0.05 \mathrm{~mol} \mathrm{~L}^{-1}$ of $\mathrm{NaCl}$ (Figure 2). All the samples exhibit a similar behavior, except

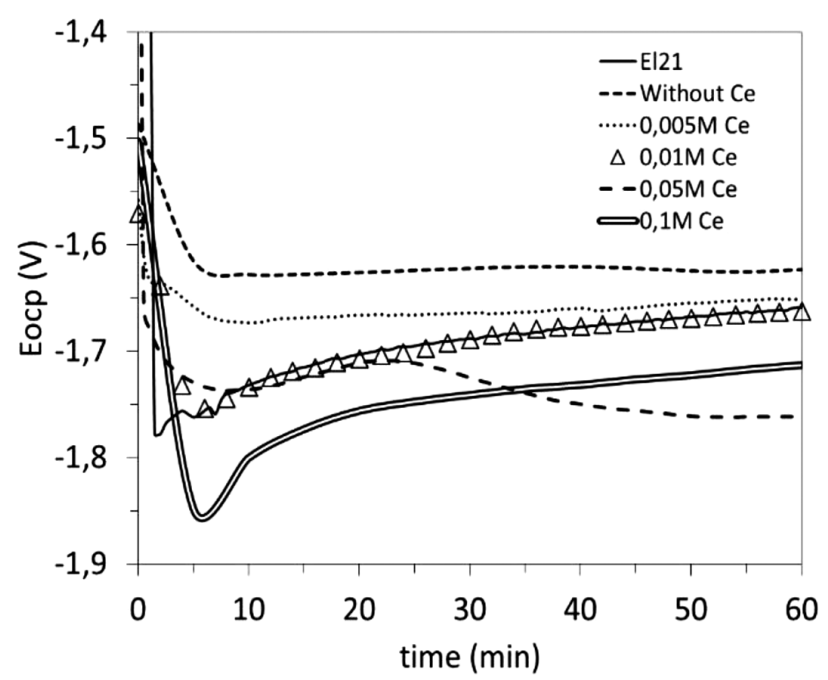

Figure 2: Evolution of the open-circuit potential $\left(E_{\text {ocp }}\right)$ of the hybrid coatings doped with cerium of different concentrations, during the immersion in a corrosive solution of $0.05 \mathrm{~mol} \mathrm{~L}^{-1}$

Slika 2: Razvoj potenciala odprtega kroga $\left(E_{\text {ocp }}\right)$ hibridnega nanosa, dopiranega s cerijem v različnih koncentracijah, med namakanjem v korozijski raztopini $0,05 \mathrm{~mol} \mathrm{~L}^{-1}$ 
the hybrid coatings that were non-doped or doped with $0.005 \mathrm{~mol} \mathrm{~L}^{-1}$ of Ce. These show a stabilized potential from the beginning of the immersion, at around $-1.63 \mathrm{~V}$ and $-1.65 \mathrm{~V}$, respectively, attributed to the insulating effect of the protective coating. In contrast, the sol-gel coatings containing $0.01 \mathrm{~mol} \mathrm{~L}^{-1}$ or higher concentrations, present a behavior similar to that of the bare El21 alloy. This is related to the growth of the passive layer and corrosion products at the surface of the substrates, due to the reaction with the electrolyte. ${ }^{6}$

Secondly, the hybrid coatings were tested with EIS after $1 \mathrm{~h}$ of the immersion in the corrosive solution, right after the OCP recording. The Bode plots of the EIS spectra obtained for different protective systems are shown in Figure 3. It is worth noting that only the hybrid coating doped with $0.1 \mathrm{~mol} \mathrm{~L}^{-1}$ presents a behavior similar to that of the bare El21 substrate. The Bode phase-angle diagram (a) shows that the last group presents two time constants, at the high and low frequencies (10 $\mathrm{kHz}$ and $1 \mathrm{~Hz}$, respectively). The first is normally attributed to the capacitive response of a hybrid sol-gel coating, which indicates that this film has a physical
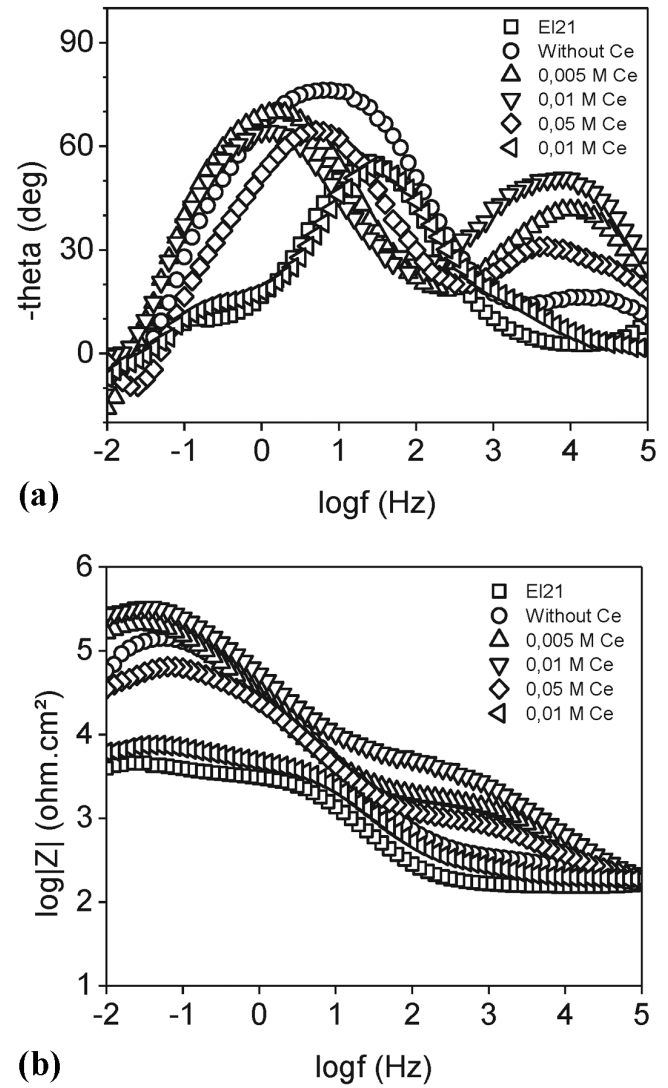

Figure 3: EIS spectra of the El21 magnesium alloy covered with the hybrid coating, doped with different concentrations of cerium. Results obtained after 1 hour of immersion in $0.05 \mathrm{~mol} \mathrm{~L}^{-1}$ of $\mathrm{NaCl}$ : a) phase-angle diagram, b) impedance modulus.

Slika 3: EIS-spektri magnezijeve zlitine El21 s hibridnim nanosom, dopiranim z različnimi koncentracijami cerija. Rezultati, dobljeni po $1 \mathrm{~h}$ namakanja v $0,05 \mathrm{~mol} \mathrm{~L}^{-1} \mathrm{NaCl}$ : a) fazni kotni diagram, b) impedančni modul. barrier effect. ${ }^{7}$ The second time constant is attributed to the presence of a porous layer in the corrosion products. ${ }^{8}$ It is important to observe that the phase angle of a hybrid coating is the highest when it is doped with $0.01 \mathrm{~mol} \mathrm{~L}^{-1}$ of cerium. On the other hand, the impedance modulus (b) obtained at a low frequency $(10 \mathrm{mHz})$ is typically assigned to the resistance of the electrochemical system, and so to its corrosion resistance. ${ }^{9}$ The cerium concentrations lower than $0.1 \mathrm{~mol} \mathrm{~L}^{-1}$, especially $0.01 \mathrm{~mol} \mathrm{~L}^{-1}$, exhibit higher impedance values. Figure 4 presents the evolution of a hybrid coating doped with $0.01 \mathrm{~mol} \mathrm{~L}^{-1}$ during its immersion in the corrosive solution. The time constant attributed to the coating gradually disappears with the immersion time (Figure $\mathbf{4 a}$, the time constant at $10 \mathrm{kHz}$ ), simultaneously with the shift of the time constant at a low frequency from $1 \mathrm{~Hz}$ to $20 \mathrm{~Hz}$. After $48 \mathrm{~h}$ of immersion, both curves, representing the bare El21 substrate and the hybrid coating, are superimposed, meaning that the coating lost its protective properties. However, the corrosion resistance of the hybrid film, depicted by the impedance modulus at a low frequency (Figure 4b) shows a progressive decrease with the time.

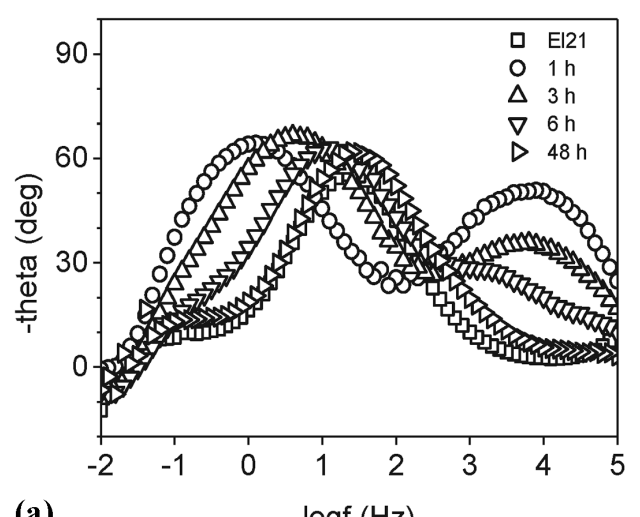

(a)

$\log (\mathrm{Hz})$

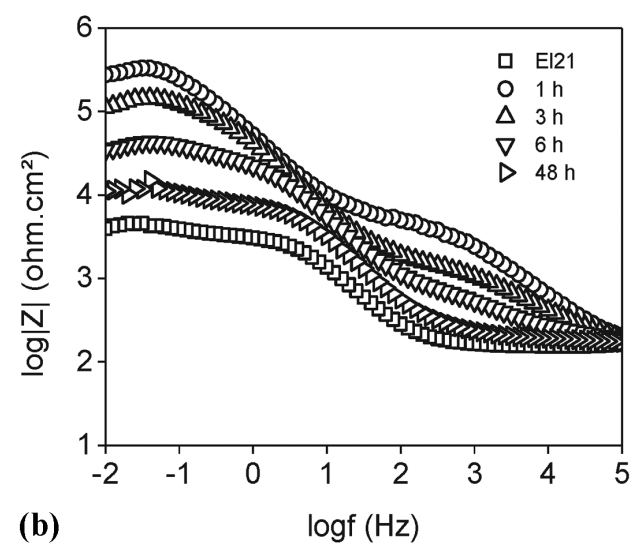

Figure 4: Bode plots of the results obtained with EIS for the hybrid coating doped with $0.01 \mathrm{~mol} \mathrm{~L}^{-1}$ of cerium, during immersion in the corrosive solution $\left(0.05 \mathrm{~mol} \mathrm{~L}^{-1}\right)$ : a) phase-angle diagram, b) impedance modulus

Slika 4: Bodejev diagram rezultatov, dobljenih z EIS hibridnega nanosa, dopiranega z $0,01 \mathrm{~mol} \mathrm{~L}^{-1}$ cerija, med namakanjem v korozijski raztopini $\left(0,05 \mathrm{~mol} \mathrm{~L}^{-1}\right)$ : a) fazni kotni diagram, b) impedančni modul 


\section{N. V. MURILLO-GUTIÉRREZ et al.: HYBRID SOL-GEL COATINGS DOPED WITH CERIUM ...}

Here, it is proven that the hybrid coating doped with $0.01 \mathrm{~mol} \mathrm{~L}^{-1}$ of cerium has the best corrosion resistance. Higher or lower concentrations of cerium decrease the coating resistance and capacitance, which leads to a rapid loss of the protective properties. ${ }^{10}$ The inhibiting properties of this element are strongly determined by the ion concentration inside the hybrid film, ${ }^{11}$ showing the existence of the optimum cerium concentration. This is due to the formation of insoluble compounds such as $\mathrm{CeO}_{2}$ and $\mathrm{Ce}(\mathrm{OH})_{3}{ }^{12}$ that temporally block the passage of the corrosive species through the hybrid coating to the metallic substrate.

\section{CONCLUSION}

A hybrid sol-gel coating offers a slight protection to a magnesium substrate during the first hours of an immersion. Moreover, an addition of cerium inside the coating with the optimum concentration of $0.01 \mathrm{~mol} \mathrm{~L}^{-1}$ leads to the increase of its anti-corrosion properties. This is due to the corrosion-inhibiting effect of cerium ions that allows a formation of insoluble compounds, enhancing the resistance of the hybrid coating to corrosive species.

\section{Acknowledgments}

The FDA and the OSEO are gratefully acknowledged for the funding provided for this project. The authors would like to thank the partners in the FUI CARAIBE project and its coordinator: the SAFRAN group.

\section{REFERENCES}

${ }^{1}$ J. E. Gray, B. Luan, Journal of Alloys and Compounds, 336 (2002), 88-113, doi:10.1515/bmt-2014-4495

${ }^{2}$ R. G. Hu, S. Zhang, J. F. Bu, C. J. Lin, G. L. Song, Progress in Organic Coatings, 73 (2012), 129-141, doi:10.1016/j.porgcoat.2011.10. 011

${ }^{3}$ E. Certhoux, F. Ansart, V. Turq, J. P. Bonino, J. M. Sobrino, J. Garcia, J. Reby, Progress in Organic Coatings, 76 (2013), 165-172, doi:10.1016/j.porgcoat.2012.09.002

${ }^{4}$ H. B. Lu, Y. Hu, M. H. Gu, S. C. Tang, H. M. Lu, X. K. Meng, Surface and Coatings Technology, 204 (2009), 91-98, doi:10.1016/ j.surfcoat.2009.06.035

${ }^{5}$ N. C. Rosero-Navarro, L. Paussa, F. Andreatta, Y. Castro, A. Duran, M. Aparicio, L. Fedrizzi, Progress in Organic Coatings, 69 (2010), 167-174, doi:10.1016/j.porgcoat.2010.04.013

${ }^{6}$ G. Baril, N. Pebere, Corrosion Science, 43 (2001), 471-484, doi:10.1016/S0010-938X(00)00095-0

${ }^{7}$ S. V. Lamaka, G. Knornschild, D. V. Snihirova, M. G. Taryba, M. L. Zheludkevich, M. G. S. Ferreira, Electrochimica Acta, 55 (2009), 131-141, doi:10.1016/j.electacta.2009.08.018

${ }^{8}$ I. A. Kartsonakis, A. C. Balaskas, E. P. Koumoulos, C. A. Charitidis, G. Kordas, Corrosion Science, 65 (2012), 481-493, doi:10.1016/ j.corsci.2012.08.052

${ }^{9}$ G. W. Walter, Corrosion Science, 26 (1986), 27-38, doi:10.1016/ 0010-938X(86)90120-4

${ }^{10}$ P. S. Correa, C. F. Malfatti, D. S. Azambuja, Progress in Organic Coatings, 72 (2011), 739-747, doi:10.1016/j.porgcoat.2011.08.005

${ }^{11}$ W. Trabelsi, P. Cecilio, M. G. S. Ferreira, M. F. Montemor, Progress in Organic Coatings, 54 (2005), 276-284, doi:10.1016/j.porgcoat. 2005.07.006

${ }^{12}$ M. F. Montemor, M. G. S. Ferreira, Electrochimica Acta, 52 (2007), 7486-7495, doi:10.1016/j.electacta.2006.12.086 